\title{
ОСОБЛИВОСТІ ВИРОБНИЦТВА МЕДУ У СХІДНИХ КРАЇНАХ
}

\author{
К. Хамід ${ }^{1}$, Ф. Аллам' \\ ${ }^{1}$ Одеський державний аграрний університет, \\ ${ }^{2}$ Директор Saudi Al Najeh Flowers Company, Czunem-OAE
}

Проведено аналіз виробництва меду в східних краӥнах, особливості застосування його у промисловості та харчуванні людей різних національностей. Вивчено специфіки експорту та імпорту меду в умовах лібералізаиії світової торгівлі.

Ключові слова: бджільництво, мед, світове виробництво, якість, експорт, імпорт

Вступ. В перспективі розвитку галузі бджільництва динаміка на світовому ринку меду буде обумовлена зростанням населення і збільшенням доходів на світовому рівні. У свою чергу це призведе до підвищення попиту на продовольство в цілому, а особливо на натуральні продукти 3 високою поживною цінністю. Споживачі все більше цікавляться тим, як зробити харчування різноманітнішим, і шукають корисні альтернативи цукру. Тому якісний мед буде користуватися підвищеним попитом серед населення будь-якої країни.

Падіння цін на мед стало також наслідком збільшення його виробництва в багатьох бджільницьких державах, виходу на світовий ринок меду нових гравців і наростання обсягів фальсифікованого меду, що поставляється на світовий ринок. На світовому ринку є високий рівень конкуренції. Для інтеграції до цього ринку й адаптації до умов його функціонування та здійснення ефективної зовнішньо-економічної діяльності необхідне інформаційне забезпечення суб'єктів щодо конкурентів, обсягу, потреб ринку та його кон'юнктури.

Проблема. Для зміцнення цін на мед на світовому ринку потрібне підвищення рівня інформованості покупців про різні аспекти і властивості продукту, забезпечення якості та безпеки меду, що поставляється, у тому числі, встановлення відповідних єдиних стандартів якості та посилення тестування, а також прозорість в питаннях походження меду, що вимагає введення систем простежуваності.

Метою статі було дослідити актуальні тенденції та ключові особливості ринку меду в Україні та східних країн з урахуванням можливостей внутрішнього виробництва й існуючого попиту за кордоном.

Аналіз останніх досліджень і публікацій. Економічним проблемам розвитку, формування та функціонування вітчизняного ринку меду приділена увага у працях Л.Л. Вакуленко, К.І. Смця, М.М. Перелигіна, О.А. Христенко. Світові тенденції на ринку меду досліджували у своїх працях Д. Воркман, N. Ören, Т. Alemdar, O. Parlakay, H. Yılmaz, A. Seçer, C. Güngör, B. Yaşar, B. Gürer [20],N. Żak [24] та інші.

Результати досліджень. Турецьке бджільництво динамічно розвивалося протягом останніх 20 років. 32000 року по 2016 рік виробництво меду виросло з 61 тис. до 106 тис. тонн, і за цим показником Туреччина посіла друге місце після Китаю. Чисельність бджільницьких сімей зросла до 6,8 млн. 90\% меду виробляється з 500 диких медоносів і 10\% - з соняшнику, ріпаку, бавовни та інших сільськогосподарських культур. Введена заборона на обробку посівів сільськогосподарських культур пестицидами шляхом розпилення.

Міністерство продовольства, сільського господарства та тваринництва плідно співпрацює 3 пасічницькою спільнотою. Турецька влада вживає заходів щодо налагодження контролю якості меду.

Туреччина повністю забезпечує потреби іï населення в меді і по його середньому споживання на одну людину припадає 1,3 кг. У турецьких супермаркетах пропонується велика різноманітність медів за ціною 8-13 дол./кг. Є й ексклюзивні меду, серед яких найбільш цінується в Туреччині Anzerbal, вироблений в провінції Різе і продається по 120 дол./кг. Найдорожчим медом в Туреччині і в світі (5тис. євро/кг) вважається Elvish Honey, кілька кілограмів якого щорічно збирають зі стін печери в районі міста Артвин. Найбільш популярні і відомі турецькі меду: акацієвий, вересковий, гірський луговий, каштановий, лавандовий, липовий, падевий сосновий $(90 \%$ світового виробництва), рододендровий, тім'яновий, квітковий і евкаліптовий. 
Туреччина входить в п’ятірку провідних світових виробників органічної меду (1,2 тис. тонн в 2016 році) і перейшла на стандарти СС в області фасування і маркування меду. Часто в магазинах можна зустріти мед 3 додаванням горіхового асорті. Це не зовсім той самий турецький мед, але досить смачна солодкість, користується невимовною популярністю у туристів. Її ціна становить 4-5 дол. за банку 200 г.

Найбільш поширений спосіб фальсифікації меду - підмішування в нього глюкози, фруктози і цукрового сиропу на етапі промислової переробки. Інший поширений спосіб фальсифікації маскування меду сумнівної якості та походження під відомі бренди. Одними з головних майданчиків збуту фальсифікованого «меду» $є$ відкриті базари, де цей продукт пропонується за ціною 2,7-4 дол./кг.

За словами виконавчого директора провідної турецької медової компанії «Altiparmak Gida Sanayive Ticaret A.S.» О. Алтіпармака (Ozen Altiparmak), 85\% меду, збувається на турецьких ринках, є фальсифікатом. Купівля меду у сільського бджоляра також не гарантує придбання натурального продукту, оскільки турецькі бджолярі «широко практикують згодовування бджолам цукрового сиропу в період головного взятку і іноді додають в збувається мед бджолині стільники для введення покупців в оману». На думку засновника медової компанії FER Bal C.Солмаза (Selcuk Solmaz), тільки мед у великих магазинах і торгових мережах, «які знаходяться під жорстким контролем і до того ж і самі перевіряють інформацію, що надходить до них продукцію», гарантовано є натуральним продуктом.

У січня 2018 медова компанія «Altiparmak Gida Sanayive Ticaret A.S.» отримала від Європейського банку реконструкції та розвитку кредит в 4,4 млн євро на розширення виробництва меду та інших продуктів бджільництва, розвиток апітерапії, навчання бджолярів передовим технологіям і створення нових робочих місць в пасічницькій індустрії, особливо для жінок, молоді та жителів віддалених районів.

Для Об'єднаних Арабських Еміратів актуальною є проблема надмірної ваги населення, тому більш здорова їжа стає популярною серед споживачів. Через все більш динамічний спосіб життя споживачі віддають перевагу готовим упакованим продуктам і все менше схильні готувати самостійно. На продажі солодких паст, включаючи мед, вплинуло введення ПДВ в ОАЕ, що призвело до підвищення цін на продукцію. Цей фактор вплинув на категорію негативно. В той же час позитивним фактором, що стимулює продажі даної категорії, є лояльність споживачів до виробників і брендів.

Дубаї - своєрідна вітрина для товарів з усього світу. Сюди приїздять дивитися продукти оптовики та трейдери з інших країн Близького Сходу та Африки. У ОАЕ створені гарні умови для ведення бізнесу іноземцями. Галузь бджільництва, виробництво і використання меду не стало винятком. В дистрибуції меду основна частка продажів займає сучасний маркетинг (86,7\% у 2018 р.), зокрема, супермаркети $(29,5 \%)$ і гіпермаркети $(57,1 \%)$. Традиційні роздрібні мережі реалізують 10,4\% обсягу меду. Продажі меду в ОАЕ протягом 2015-2018 рр. значно зросли - на 57\%. Проте динаміка зростання уповільнилась, починаючи з 2016 р. Згідно прогнозу, протягом 2019-2022 pр. продажі меду стабільно зростатимуть на рівні 6-7\% щороку. Сегмент меду в ОАЕ $\epsilon$ сильно концентрованим - два лідери займають 67\% ринку. Серед провідних постачальників продукції переважно іноземні компанії, як регіональні (Sunbulah Group, Саудівська Аравія), так i європейські (Fürsten-Reform Dr Med Hans Plümer Nachf GmbH \& Co, Narimpex AG ).

Бджільництво Єгипту не просто розвинене, а $€$ одним 3 топових напрямків в сільськогосподарської промисловості. Вся справа в сприятливих умовах, які довільно створюються для отримання корисної та дуже смачного меду.

Від рослин залежить успіх бджільництва, адже саме вони забезпечують бджіл тим самим нектаром - сировиною для майбутнього меду. Так, весна - це період цвітіння цитрусових рослин, а також конюшини. Літо відомо активним цвітінням баштанних, люфа і бавовнику. Зима - це не період відпочинку, адже в зимовий час в Сгипті активно ростуть і розвиваються овочеві культури, які є джерелом меду.

Після свого «туру» по річці Ніл від Асуана до Каїра бджолярі поверталися тільки до літа, і обов'язково з хорошим «урожаєм» меду. Саме в Каїрі реалізують мед, після чого з приходом осені знову поверталися в «кочування» в південну частину країни. Мед з Єгипту славиться в усьому світі, тому вважається дуже розвиненим. Середні показники по країні становлять приблизно 680 - 
700 тисяч вуликів. Це своєрідний «будинок» для місцевої «королеви» - єгипетської бджоли. Вулики в єгиптян не розбираються і мають свою назву - Ель-баладня особливу увагу в Міністерстві сільського господарства Сгипту приділяється саме розведення та вдосконалення бджільництва.

Внесок бджільництва в економіку Сгипту (запилення сільгоспкультур, виробництво меду та інших продуктів бджільництва і т.і.) оцінюється в 2,4 млрд дол. Продуктивність середньої бджолосім'ї - 5 кг товарного меду в рік. Середньодушове споживання меду в 2019 році склало 25 грам на рік - в 8 разів менше середньосвітового рівня.

В Алжирі бджільництво також добре розвивається. Найчастіше в Алжирі зустрічаються маленькі пасіки до 10 бджолосімей, часто сімейні, це викликано як традиціями, так і мізерністю медоносної бази - основна частина території країни це пустеля або скелясті гори (та ж пустеля, але кам'яна). Але на півночі Алжиру розташовуються гори Атласу, покриті лісами, де багато медоносів, на узбережжі $є$ водно-болотні угіддя, де також багато медоносів. Також на зрошуваних полях вирощуються культури потребують запилення і $є$ медоносами - баштанні та інші, а також цитрусові і фруктові сади.

Сьогодні алжирські бджолярі дуже різноманітні за своїм менталітетом, від традиційного сільського, до сильно розвиненого підприємницького. Слабкий державний нагляд у поєднанні 3 підприємливістю бджолярів привів до багатьох форм спонтанної організації, зокрема у формі різних асоціацій або груп економічних інтересів.

Виробництво меду в Ірані зросло на 10\% 32018 року по порівнянні 3 показником за аналогічний період 2017 року, розповів глава ради директорів Асоціації бджолярів і виробників меду Ірану (Iranhoney).

Збільшення кількості опадів в північних, західних і центральних районах країни навесні стало причиною зростання виробництва, розповів Абдольреза Бігон газеті Iran Daily. B середньому з одного вулика можна отримати 11 кг меду, а в деяких регіонах від 20 до 40 кг.

Також зазначив, що іранські провінції Східний Азербайджан (північно-західний Іран) Мазендаран (північний Іран) і Ардебіль (північний Іран) займають перші три місця в країні, відповідно, з виробництва меду. Описуючи провінцію Ардебіль, як центр виробництва меду в Ірані, він зазначив, що мед, вироблений на горі Сабалан в Ардебіль, користується світовим попитом.

Споживання меду в Ірані вважається високим у порівнянні з іншими країнами. Застосування меду на душу населення в світі становить 250-300 г, а в Ірані - майже 1 кг, тобто в 3 рази більше світової середини. Хоча Іран може знайти в регіональних країнах хороші ринки для експорту меду, високе вживання меду і економічна прибутковість даного продукту в країні призвело до того, що виробники не зацікавлені експортувати свою продукцію.

Зазначено, що експорт меду з Ірану за 2018 рік склав 700 тонн, і висловив жаль 3 приводу того, що через війни, конфліктів і криз в регіоні, зарубіжний продаж продукту в такі країни, як Сирія, Саудівська Аравія і Смен, зменшився.

Основними покупцями іранського меду є країни Перської затоки, а також ряд країн південно-східної Азії, таких як Малайзія і Бруней.

Афганістан на протязі певного часу постачає на експорт високоякісний бджолиний мед. У 2009 році був зданий в експлуатацію перший цех з пакування меду у банках на бджільницькій фермі у східній афганській провінції Нангархар.

За даними радіостанції «Free Afghanistan» бджільницьку ферму організували місцеві підприємці за сприяння американського Агентства міжнародного розвитку (USAID). На мінізаводі працювало лише 15 осіб, проте продуктивність цеху перевищувала 400 кг банкового меду 3 фірмовою етикеткою Ісламської Республіки Афганістан.

Афганський мед, знаний своєю якістю і чудовими смаковими властивостями, був добре знайомий європейцям ще в 1980-х роках. Проте десятиліття війни підірвали основи афганського сільського господарства і знищили державні ферми.

Донині в афганських магазинах можна було знайти тільки мед, виготовлений і розфасований в Арабських Еміратах або Німеччині. Щоправда, мандрівники, ризикнувши проїхати через країну автівкою, могли придбати натуральний ароматний мед дорогою з Кабула до північних афганських провінцій: на гірських перевалах Північного і Південного Салангу вздовж траси Кабул - Балх 
можна часто побачити ряди бджолиних вуликів і намети місцевих підприємців, які чекають іноземців в надії заробити. Вартість кілограмової банки запашного салангського меду, зазвичай, не перевищує 150 афгані (менше 5 дол.).

Щоб довести «рукотворність» пропонованого ними продукту, афганські виробники зазвичай кидають до банки з медом кілька живих бджіл зі своїх вуликів, які, потонувши в густій рідині, служать екзотичною прикрасою товару.

За даними радіостанціï "Free Afghanistan", мед афганських фермерів одержав вищу оцінку експертів на регіональній виставці сільгоспвиробників, яка проходила нещодавно в Індії.

Бджільництво Судану також на протязі останніх років починає розвиватися. На початку 2012 року Міністерство тваринництва, рибальства та лісового господарства провело конференцію 3 проблем бджільництва; був створена Спілка бджолярів Судану, яка увійшла до Торгово промислової палати цієї країни; підписано угоду про співпрацю з Програмою ООН з розвитку.

Споживання меду в Кувейті щорічно зростає на 3\%, що пояснюється, зокрема, швидким зростанням населення. У 1997 р в країну було імпортовано 714 т меду, в тому числі з Австралії 231 т, США -193, Саудівської Аравії - 73, Німеччині - 46 т. Невеликі партії меду закуповували також у Великобританії, Франції, Туреччини, Греції, Лівані та інших країнах. За прогнозами, імпорт меду найближчим часом складе 950-1000 т.

У Кувейті немає мит на продовольчі товари, імпортних квот, імпортних ліцензій та інших нетарифних обмежень. Нові імпортні товари обов'язково перевіряють на якість і відповідність місцевим стандартам. Якщо продукт проходить первинний тест гладко, то наступні його партії звільняють від перевірок протягом деякого часу (зазвичай на півроку). Імпортом меду займаються 20-25 приватних компаній, але вирішальну роль грають лише 10 з них. У роздрібну торгівлю направляється 80\% імпортного меду, в лікарні, армійські підрозділи і інші державні структури 10 , в харчову промисловість - $10 \%$.

Помітних успіхів у розвитку бджільництва домоглася Сирія, чому активно сприяє уряд країни. Протягом останнього десятиліття бджолярам тут надають пільгові кредити терміном на п’ять років для обзаведення пасіками. Побудовано п'ять заводів з виробництва вуликів (10 тис. Штук на рік). В даний час в країні виробляють 1750 т меду, тут налічується 365 тис. Сімей бджіл, (80\% містять у вуликах Лангстрота) 15 тис. бджолярів, з них 5 тис. професіонали (мають 100 i більше сімей).

Сирійський мед користується високою репутацією на світовому ринку, оскільки не містить залишків пестицидів і лікарських препаратів. Основні медоноси: цитрусові, евкаліпт, аніс, соняшник, плодові дерева, бавовник, верес, чебрець, розмарин, чортополох і т.д. Бджолярів і довести чисельність бджолиних сімей до 0,5 млн. Для цього відкриті 20 шкіл, в яких слухачів навчають сучасним технологіям бджільництва. Щорічно вони випускають по 300 спеціалістів.

В рамках програми розвитку бджільництва здійснюється озеленення безліса гірських районів посадками евкаліпа, акації та інших медоносів. Передбачається також ширше використовувати бджіл для запилення плантацій фруктових дерев. Ціни на мед на місцевому ринку складають 7-24 євро (в перерахунку з сирійського фунта) за 1 кг. Щорічно в Сирії виробляють близько 300 кг маточного молочка, ціна якого досить висока -2 євро за 1 м.

Бджільництво Ізраїлю має багатовікові традиції, бджоли і продукти бджільництва неодноразово згадуються в Талмуді і Біблії, а місцевість, яку займає в даний час країна, характеризувалася як "поточна молоком і медом". Давні традиції живі, бджільництво Ізраїлю може служити прикладом в правовому і організаційному відношенні.

В даний час в країні налічується 90 тисяч бджолиних сімей, що містяться в основному у вуликах Лангстрота. 450 бджолярів, в тому числі 50 професіоналів, виробляють в середньому 3,5 тисяч тон меду. Бджільництвом займаються як бджолярі-любителі, так і кооперативи, а також кибутца i мошави. Вважається, що при професійному веденні бджільництва економічно доцільним є зміст на одного бджоляра 700, на двох - 1000-1200 бджолиних сімей.

Одним з основних напрямків спеціалізації бджільництва є використання бджіл на запиленні сільськогосподарських культур: цитрусових, авокадо, соняшнику, суниці, огірків і динь в теплицях.

30-40\% медозбору доводиться на цитрусові в березні-квітні, в травні-червні медозбір забезпечують евкаліпти і різнотрав'я, потім - соняшник і бавовник. На спеціалізованих пасіках 
одержують від бджолиної сім'ї до 50-60кг меду - рекорт - 110 кг, а бджолярі-любителі - в середньому 20-30кг. Мед з цитрусових - світлий, а з авокадо - темний.

Спілка виробників і торговців медом захищає права бджолярів і відстоює їх інтереси в державних інстанціях. Він же регламентує ціни і займається торгівлею медом, продаж цього продукту бджіл на ринку заборонена.

Ізраїльська спілка бджолярів займається питаннями модернізацій бджільництва і підтримку міжнародних зв'язків, контактує зі Спілкою виробників меду, здійснює реєстрацію бджолярів і забезпечує регульоване використання медоносної бази, веде сучасну систему обліку, становить картотеку, стежить за системою маркетингу, за станом імпорту-експорту. Вхідні у спілку бджолярі несуть за здійснення цієї роботи витрати на рівні 4,5 доларів США на кожну бджолину сім'ю. Для проведення наукових досліджень виділяється 5\% коштів від виробленого меду.

Наукове забезпечення здійснюють кафедра бджільництва сільськогосподарського факультету Тель-Авівського університету і Дослідна станція бджільництва в Цріфін.

Асортимент обладнання для відкачки меду дуже різноманітний, на великих пасіках стільники роздруковують механічно і відкачують на 100-120-рамкових медогонках, мед фільтрують і після м'якого підігріву фасують в дрібну тару.

Що стосується України, то український ринок меду є одним з найбільш перспективних і розвивається на сьогодні найшвидше 3 усіх агропромислових галузей країни. Світове виробництво меду становить 1,5 млн т на рік, і на частку України припадає 5\%. Експорт меду 3 України зріс у 2019 році на 12,7\%, до 55,6 тис. т. Виручка від поставок меду на зовнішні ринки у минулому році склала понад 100 млн дол.

Міжнародний консультант ФАО, аналітик сільськогосподарських ринків Андрій Панкратов на тренінгу для українських експортерів «Sweet Trade: Как успешно экспортировать сладости, фрукты, ягоды и орех из Украины в Ближней Восток» виділив серед перспективних країн для українського меду наступні:

- Ірак, який за останній рік наростив імпорт меду на 255,9\%, але який одночасно імпортує 3 України в середньому 30 т/p.;

- OAE з ростом імпорту на 23\%, але які не закуповують мед в Україні;

- Саудівська Аравія, де імпорт знизився на 1,2\%;

- Катар з ростом імпорту на 18,6\%, не закуповує український мед;

- Кувейт - зростання імпорту $11,9 \%$, не закуповує український мед;

- Йорданія - імпорт зріс на 10,3\%, не закуповує український мед;

- Ізраїль - імпорт зріс на 36,2\%, імпортує з України в середньому 33 т меду.

Починаючи 31 вересня 2020 року, підприємства - виробники меду та продуктів бджільництва мають змогу експортувати свою продукцію до Королівства Саудівська Аравія за формою сертифіката, яка була погоджена між компетентними органами України та КСА. Зазначається, що наразі до переліку ухвалених підприємств, які акредитовані для експорту меду та продуктів бджільництва до Королівства Саудівська Аравія увійшли 7 українських підприємств, зокрема: ТОВ «Сан Бі Україна»; ФГ «Апіс Україна»; ТОВ «Біхайв»; ТОВ «Медовий край»; ФОП «Косовська Л.В.»; ТОВ «Юбі»; ТОВ «СП „Мед Поділля“». Також, починаючи 32018 року розпочав свою роботу онлайн-супермаркет Redmart, що належить лідеру онлайн-торгівлі AlibabaGroup, та $є$ одним із найважлівішіх торговельних майданчиків Підвенно-Східної Азії, розпочав продаж у Сингапурі меду виробництва української компанії Асканія-Пак. Наразі в Redmart представлено 12 видів меду від Асканія-Пак у роздрібній упаковці: липовий, акацієвий, гречаний та Луговий мед, а також лінійка крем-медів з різними смаками - полуниці, абрикосу, лохини, лимону та м’яти, шоколаду та іншими. Вартість продукту становить \$14 за банку меду та $\$ 12,5$ за банку крем-меду.

Висновки. Перспективи виробництва меду у світі, зокремав східних країнах безпосередньо пов'язані із необхідністю збереження досягнутих останніми роками обсягів виробництва продукції та забезпечення сталого розвитку галузі. Для цього слід розвивати цю галузь не лише серед бджолярів-любителів, але й підприємців.

Необхідно проводити спільні конференції, семінари, курси підвищення кваліфікації, проводити обмін досвідом введення галузі бджільництва, застосовувати сучасний інвентар, 
обладнання та механізми для отримання продукції, ветеринарно-санітарні заходи на пасіках, використовувати сучасні методи визначення якості меду та іншої продукції бджільництва.

\section{Список використаних джерел}

1. Вакуленко Л.Л. Експорт та імпорт меду натурального та іншої сільськогосподарської продукції; сучасний стан і проблеми // Вісник аграрної науки Причорномор'я : зб. наук. пр. Миколаїв: МДАУ, 2007. Вип.2 (40). С.79-86. (Серія “Економічні науки”).

2. Корженівська Н. Розвиток галузі бджільництва - джерело продовольчої безпеки. Світовий досвід у галузі бджільництва та перспективи розвитку в Україні: Збірник наукових праць Міжнародного науково-практичного форуму, 2018 р. Кам'янець-Подільський: ПДАТУ, 2018. C.53-55.

3. An economic analysis of beekeeping activities in Adana. Ören N., Alemdar T., Parlakay O., Yılmaz H., Seçer A., Güngör C., Yaşar B., Gürer B. Publication no. 178. Ankara, Agricultural Economic and Policy Development Institute, 2010. Turkey

4. Żak N. Honey market in the opinion of young consumers. Handel wewnętrzny. 2017. Vol. 1(366). Pp. 424-438.

5. https://mandry.club/cikavi-facty/shho-mozhna-privezti-z-turechchini-idei-podarunkiv.

6.

https://www.unian.ua/society/222004-afganistan-gotoviy-postachati-na-eksportvisokoyakisniy-med.html

\section{ОСОБЕННОСТИ ПРОИЗВОДСТВА МЕДА В СТРАНАХ ВОСТОКА}

Хамид К., Аллам Ф.

Анализ производства меда в разных странах, особенности использование эго в производстве и питании людей разных национальностей. Овцеводческие особенности экспорта и импорта меда в условиях либерализации мировой торговли.

Ключевые слова: пчеловодство, мед, мировое производство, качество, экспорт, импорт.

\section{FEATURES OF HONEY PRODUCTION IN EASTERN COUNTRIES}

Khamid K., Allam F.

An analysis of honey production in different countries, Features! The use of ego in industry and nutrition of people of different nationalities. Sheep specifics of export and import of honey in the conditions of liberalization of World trade.

Key words: beekeeping, honey, world production, quality, export, import. 